\title{
SOLUBLE CARBON IN OXISOL UNDER THE EFFECT OF ORGANIC RESIDUE RATES ${ }^{(1)}$
}

\author{
Gabriela Lúcia Pinheiro ${ }^{(2)}$, Carlos Alberto Silva ${ }^{(3)}$ \& José Maria de Lima ${ }^{(3)}$
}

\begin{abstract}
SUMMARY
The application of organic residues to the soil can increase soluble organic carbon (SOC) and affect the $\mathrm{pH}$ and electrolytic conductivity (EC) of the soil. However, the magnitude of these changes depends on the type of residue and the applied dose. This study aimed to evaluate the effect of increasing $\mathrm{C}$ rates contained in organic residue on the $\mathrm{pH}, \mathrm{EC}$, water-extractable total carbon (WETC), waterextractable organic carbon (WEOC), and water-extractable inorganic carbon (WEIC) in soil treated with manure (chicken, swine, and quail), sawdust, coffee husk, and sewage sludge. The levels of total $\mathrm{C}\left(\mathrm{TC}-\mathrm{KH}_{2} \mathrm{PO}_{4}\right)$, organic carbon $\left(\mathrm{OC}-\mathrm{KH}_{2} \mathrm{PO}_{4}\right)$, and inorganic $\mathrm{C}\left(\mathrm{IC}-\mathrm{KH}_{2} \mathrm{PO}_{4}\right)$ extractable by a $0.1 \mathrm{~mol} \mathrm{~L}^{-1} \mathrm{KH}_{2} \mathrm{PO}_{4}$ solution were also quantified in soil under the effect of increasing rates of chicken and quail manures. The following rates of organic residue $\mathrm{C}$ were applied to a dystrophic Red Latosol (Oxisol) sample: 0, 2,000, 5,000, 10,000, and $20,000 \mathrm{mg} \mathrm{kg}^{-1}$. The addition of organic residues to the soil increased $\mathrm{pH}$, except in the case of sewage sludge, which acidified the soil. The acidity correction potential of chicken and quail manure was highest, dependent on the manure rate applied; regardless of the dose used, sawdust barely alters the soil $\mathrm{pH}$. At all tested rates, the EC of the soil treated with swine manure, coffee husk, and sawdust remained below 2.0 $\mathrm{dS} \mathrm{m}^{-1}$, which is a critical level for salinity-sensitive crops. However, the application of chicken or quail manure and sewage sludge at certain rates increased the EC to values above this threshold level. Highest levels of WETC, WEOC, and WEIC were obtained when chicken and quail manure and coffee husk were applied to the Oxisol. The quantities of SOC extracted by $\mathrm{KH}_{2} \mathrm{PO}_{4}$ were higher than the quantities extracted by water, demonstrating the ability of soil to adsorb $\mathrm{C}$ into its colloids.

Index terms: soluble organic carbon, manure, electrolytic conductivity, soil acidity, crop residues, carbon adsorption.
\end{abstract}

\footnotetext{
(1) Part of the Thesis of the first author, Soil Science Post Graduation Program - Soil Science Department, Federal University of Lavras - UFLA. Received for publication on May 2, 2013 and approved on January 13, 2014.

(2) Post Doctoral student in Soil Science, Soil Science Department, Federal University of Lavras - UFLA. Postal Box 3037. CEP 37200-000 Lavras (MG), Brazil. CAPES scholarship. E-mail: gabriela.solos@gmail.com

(3) Professor, Soil Science Department, UFLA. E-mail: csilva@dcs.ufla.br, jmlima@prp.ufla.br
} 


\title{
RESUMO: CARBONO SOLÚVEL EM LATOSSOLO SOB EFEITO DE DOSES DE RESIDDUOS ORGÂNICOS
}

\begin{abstract}
A adição de resíduos orgânicos pode aumentar o carbono orgânico solúvel (COS) e alterar o $\mathrm{pH}$ e a condutividade elétrolítica (CE) do solo, mas a magnitude dessas variações depende do resíduo e de sua dose aplicada. Objetivou-se avaliar o efeito de doses de carbono pela adição de resíduos orgânicos sobre o $\mathrm{pH}$, a CE, o carbono total extraível por água (CTEA), o carbono orgânico extraível por água (COEA) e o carbono inorgânico extraivel por água (CIEA), em solo tratado com estercos (galinha, suíno e codorna), serragem, casca de café e lodo de esgoto. Os teores de $\mathrm{C}$ total $\left(\mathrm{CT}-\mathrm{KH}_{2} \mathrm{PO}_{4}\right)$, C orgânico $\left(\mathrm{CO}-\mathrm{KH}_{2} \mathrm{PO}_{4}\right)$ e C inorgânico $\left(\mathrm{CI}-\mathrm{KH}_{2} \mathrm{PO}_{4}\right)$ extraível por solução de $\mathrm{KH}_{2} \mathrm{PO}_{4} 0,1 \mathrm{~mol} \mathrm{~L}^{-1}$ também foram quantificados em solo sob efeito de doses crescentes de estercos de galinha e de codorna. O solo utilizado foi o Latossolo Vermelho distroférrico (LVdf) e as doses de C-resíduo orgânico constituíram-se de 0, 2.000, 5.000, 10.000 e $20.000 \mathrm{mg} \mathrm{kg}^{-1}$. A adição de residuos orgânicos ao solo promoveu aumento do $\mathrm{pH}$, exceto no caso do lodo de esgoto, que acidificou o solo. Os estercos de galinha e de codorna apresentaram os maiores potenciais de correção da acidez do solo, cuja magnitude é dependente da dose de esterco aplicada; independentemente da dose utilizada, a serragem pouco altera o pH do solo. A CE do solo tratado com esterco de suíno, casca de café e serragem, em todas as doses avaliadas, manteve-se abaixo de $2,0 \mathrm{dS} \mathrm{m} \mathrm{m}^{-1}$, nível crítico para culturas sensiveis à salinidade. Entretanto, a aplicação de estercos de galinha e de codorna e de lodo de esgoto, para algumas doses, elevou a CE para valores acima desse nível crítico. Os maiores teores de CTEA, COEA e CIEA foram obtidos quando se adicionaram ao Latossolo os estercos de galinha e de codorna e a casca de café. As quantidades de COS extraídas por $\mathrm{KH}_{2} \mathrm{PO}_{4}$ foram maiores que as extraidas por água, evidenciando a capacidade de o solo adsorver $C$ em seus coloides.
\end{abstract}

Termos de indexação: carbono orgânico solúvel, estercos, condutividade eletrolítica, acidez do solo, resíduos vegetais, adsorção de carbono.

\section{INTRODUCTION}

Although the soluble organic carbon (SOC) fraction represents only a small portion of the total organic carbon (TOC) in the soil (Metting, 1993), it constitutes the most mobile and reactive $\mathrm{C}$ fraction (Marschner \& Kalbitz, 2003) and is involved in several processes that occur in the soil (Chantigny, 2003). This fraction consists of the intermediate products of organic residue degradation, such as proteins, carbohydrates, hydrocarbons, and their derivatives, as well as of fractions of low-molecular-weight, humic substances and numerous other simpler organic compounds (Gonet \& Debska, 2006). The SOC is often defined as a soluble fraction that passes through a membrane with 0.45 - $\mathrm{mm}$ pore diameter (Solinger et al., 2001). However, other operational definitions have been proposed, according to the extraction procedure (Zsolnay, 1996). In this study, the term waterextractable organic carbon (WEOC) refers to the SOC fraction that includes all forms of water-soluble organic carbon (Chantigny, 2003).

Numerous organic residues have potential uses in agriculture, including manure, industrial residues, sewage sludge, vinasse, several effluents, and coffee husk. These residues have widely variable $\mathrm{pH}$, electrolytic conductivity (EC), C content and nutrient levels; thus, some act as $\mathrm{N}$ sources, others as sources of $\mathrm{K}$, some of $\mathrm{P}$, and others act as soil conditioners, depending on the rate applied, increasing the cation exchange capacity (CEC) and improving the soil structure and, thus, the water retention capacity of the soil (Montemurro et al., 2004; Montemurro \& Maiorana, 2008; Melo et al., 2008; Higashikawa et al., 2010). In addition to improved soil properties, the soil $\mathrm{pH}$ has been shown to increase as a result of the application of organic matter (Franchini et al., 1999; Zheljazkov \& Warman, 2004; Mkhabela \& Warman, 2005; Zhang et al., 2006). Likewise, EC has been shown to increase by the application of municipal waste compost (Abreu Junior et al., 2000; Oliveira, 2000), tannery sludge (Aquino Neto \& Camargo, 2000), and sewage sludge (Fia et al., 2005; Teixeira et al., 2005). Chicken and quail manure can cause salinization due to their high EC values, depending on the rate and frequency with which they are added to soil (Melo et al., 2008). Therefore, residues should be applied to the soil obeying technical criteria as, in some cases, they may represent a potential environmental polluter due to changes in $\mathrm{pH}$ and increases in $\mathrm{EC}$ and salinity, which may compromise soil and water quality (Wright et al., 2005), especially when these materials are continually used at high rates.

There are already reports on soils used for vegetable cultivation in the Southern State of Minas Gerais, Brazil, where the continued use of manure can increase the $\mathrm{pH}$ to values above the recommended levels for the cultivation of most crops. Because manure, primarily chicken manure, is applied more than once annually to vegetable fields, the cumulative loads of manure may represent approximately 40 tha $^{-1}$ in less than four years of cultivation. These excessive loads of manure may also affect the EC, but the effects 
of manure on this property have not yet been evaluated. The treatments tested in this study are based on this history of continuous and high manure use and its possible adverse effects on soil and plants. The evaluations were restricted to the short term, given that excessive increases in $\mathrm{pH}$ and possibly $\mathrm{EC}$ may compromise plant growth during the initial days of growth for short-cycle vegetable crops. In addition, studies aiming to evaluate soluble $\mathrm{C}$ in Brazilian soils are scarce, especially studies to measure soluble organic $\mathrm{C}$ and $\mathrm{C}$ in the form of $\mathrm{CaCO}_{3}$, which predominates in chicken and quail manure and in soil treated with these residues. The research actions proposed in this study are based on the fact that increased presence of soluble $\mathrm{C}$ in the soil may mitigate the adverse effects of excessive increases in $\mathrm{pH}$ and EC continuously fertilized with manure.

As previously mentioned, the agricultural use of organic residues can increase the SOC levels and affect nutrient and metal mobility in soils (Chantigny et al., 2002; Wright et al., 2005). Because increasing SOC is associated with increased TOC content (Ciotta et al., 2004), it is expected that systems that receive higher quantities of soil organic matter also have higher SOC levels (Inácio, 2009). The SOC concentration is also affected by the chemical composition of the organic residues added to the soil (Cerný et al., 2003; Xu et al., 2006), especially organic matter with a low degree of decomposition (Asmar et al., 1994) and/or organic residues with elevated soluble organic compound levels that promote immediate increases in SOC levels (Chantigny et al., 2002).

Several procedures used for extracting SOC are described in the scientific literature, which differ regarding the extractor used (Madhun et al., 1986; Kennedy et al., 1996), extraction time (Madhun et al., 1986; Zsolnay \& Steindl, 1991), and soil:extraction solution ratio (Negrin et al., 1996; Gigliotti et al., 1997). Gonet \& Debska (2006) found that the quantities of SOC extracted from soils depend on the extractor properties and that a borate buffer solution extracts more $\mathrm{C}$ than $0.004 \mathrm{~mol} \mathrm{~L}^{-1} \mathrm{CaCl}_{2}$. Bolan et al. (1994) and Baziramakenga et al. (1995) found that extraction solutions such as $0.1 \mathrm{~mol} \mathrm{~L}^{-1} \mathrm{HCl}$ and $0.1 \mathrm{~mol} \mathrm{~L}^{-1} \mathrm{NaOH}$ extract organic compounds more efficiently than water.

Considering the high adsorption of organic compounds by the mineral fraction of the soil used in this study, it is believed that the use of water as an extractor may underestimate the SOC levels and that $\mathrm{KH}_{2} \mathrm{PO}_{4}$ is more efficient in the extraction process, given that phosphate has a high affinity for adsorption sites occupied by organic ligands (Shen et al., 1996), which are released into the SOC solution. Furthermore, it is expected that the $\mathrm{pH}, \mathrm{EC}$ and $\mathrm{C}$ levels extracted by water and $\mathrm{KH}_{2} \mathrm{PO}_{4}$ will be higher in soils incubated with higher rates of nutrient-rich organic residues and organic residues with a low degree of decomposition. In view of the foregoing, this study had the following objectives: evaluate the $\mathrm{pH}$, EC, water-extractable total carbon (WETC), waterextractable organic carbon (WEOC), and waterextractable inorganic carbon (WEIC) in soil samples treated with increasing levels of $\mathrm{C}$ contained in organic residues; and quantify WETC, WEOC, and WEIC and the total C (TC- $\mathrm{KH}_{2} \mathrm{PO}_{4}$ ), organic C (OC- $\left.\mathrm{KH}_{2} \mathrm{PO}_{4}\right)$, and inorganic $\mathrm{C}\left(\mathrm{IC}-\mathrm{KH}_{2} \mathrm{PO}_{4}\right)$ extractable by $\mathrm{KH}_{2} \mathrm{PO}_{4}$ solution in soil samples incubated with increasing rates of chicken and quail manure.

\section{MATERIAL AND METHODS}

A soil sample (0-5 cm layer) of a dystrophic Red Latosol (Oxisol) (LVdf, $66 \%$ clay) was used in the study, chosen for its high $\mathrm{C}$ content $(4.4 \%)$. After sampling, the soil samples were air-dried, ground, and sieved (2-mm mesh) to obtain air-dried fine soil, and stored in a dry place. The main properties of the study soil were $\mathrm{pH}\left(\mathrm{H}_{2} \mathrm{O}\right)(1: 2.5)=4.2 ; \mathrm{P}$ (Mehlich-1) $=2.0 \mathrm{mg} \mathrm{dm}^{-3} ; \mathrm{K}=59 \mathrm{mg} \mathrm{dm}^{-3} ; \mathrm{Ca}=0.2 \mathrm{cmol}_{\mathrm{c}} \mathrm{dm}^{-3}$; $\mathrm{Mg}=0.2 \mathrm{cmol}_{\mathrm{c}} \mathrm{dm}^{-3}$; and $\mathrm{V}=3.0 \%$. Before incubation with organic residues, $200 \mathrm{mg} \mathrm{kg}^{-1} \mathrm{P}$ as $\mathrm{Ca}\left(\mathrm{H}_{2} \mathrm{PO}_{4}\right)_{2}$ p.a., $3.37 \mathrm{~g} \mathrm{~kg}^{-1}$ as $\mathrm{CaCO}_{3}$ and $0.94 \mathrm{~g} \mathrm{~kg}^{-1}$ of $\mathrm{MgCO}_{3}$ were added to the soil to raise base saturation to $60 \%$ (Raij, 1991). The soil moisture content was maintained close to field capacity and the temperature at approximately $20{ }^{\circ} \mathrm{C}$, for 15 days. Next, the soil matter was dried in a forced circulation oven at $70^{\circ} \mathrm{C}$ and fertility was analyzed. The main properties of the Oxisol sample after $\mathrm{P}$ application and acidity correction were $\mathrm{pH}\left(\mathrm{H}_{2} \mathrm{O}\right)(1: 2.5)=6.3 ; \mathrm{P}($ Mehlich-1) $=18.6 \mathrm{mg} \mathrm{dm}^{-3} ; \mathrm{K}=299 \mathrm{mg} \mathrm{dm}{ }^{-3} ; \mathrm{Ca}=5.7 \mathrm{cmol}_{\mathrm{c}} \mathrm{dm}^{-3}$; $\mathrm{Mg}=1.6 \mathrm{cmol}_{\mathrm{c}} \mathrm{dm}^{-3}$; and $\mathrm{V}=61.5 \%$.

The organic residues used in this study consisted of chicken, swine, and quail manure, sawdust, coffee husk, and sewage sludge. Table 1 shows the main chemical and physicochemical properties of the organic material used in the study; these data were compiled by Pinheiro et al. (2013). The macronutrient and micronutrient levels of some of the residues were reported by Higashikawa et al. (2010).

Centrifugation tubes of $60 \mathrm{~mL}$ were filled with 20 $\mathrm{g}$ of soil sample, to which varying quantities of organic residues were added, containing $0,2,000,5,000,10,000$ and $20,000 \mathrm{mg} \mathrm{kg}^{-1} \mathrm{C}$. These rates simulate the residue loads applied in the cultivation of different crops, especially of vegetable crops, in nursery beds with continued use of manure. The experiment was arranged in a completely randomized design (CRD) with $a(6 \times 5) \times 3$ factorial scheme, i.e., six organic residues combined with five rates of organic residue $\mathrm{C}$ with three replicates for each treatment, for a total of 90 experimental units.

The incubation period of the soil with organic residues was 30 days; during this period, soil moisture was maintained adding water in order to reach 
Table 1. Main chemical and physicochemical properties of the organic residues used in the study

\begin{tabular}{|c|c|c|c|c|c|c|}
\hline Organic residue & $\mathbf{C}$ & WEOC & $\mathbf{N}$ & $\mathrm{C} / \mathrm{N}$ & $\mathrm{pH}\left(\mathrm{H}_{2} \mathrm{O}\right)$ & EC \\
\hline & dag $\mathrm{kg}^{-1}$ & $\mathrm{mg} \mathrm{kg}^{-1}$ & $\%$ & & & $\mathrm{dS} \mathrm{m}^{-1}$ \\
\hline Chicken manure & 22.7 & 31,80 & 4.8 & 4.7 & 7.1 & 6.6 \\
\hline Quail manure & 25.5 & 32,10 & 2.4 & 10.6 & 7.1 & 7.4 \\
\hline Swine manure & 26.3 & 13,10 & 2.0 & 13.1 & 7.7 & 2.8 \\
\hline Sawdust & 44.6 & 3,58 & 0.3 & 131 & 4.4 & 1.5 \\
\hline Coffee husk & 42.0 & NA & 3.0 & 14.0 & 4.7 & 6.3 \\
\hline Sewage sludge & 19.8 & 3,23 & 2.2 & 9.0 & 3.4 & 3.3 \\
\hline
\end{tabular}

WEOC, water-extractable organic carbon; C/N, C/N ratio; EC, electrolytic conductivity; NA, not analyzed.

Source: data compiled by Pinheiro et al. (2013).

contents in soil close to $70 \%$ of field capacity. The initial volume of water required for wetting the soil samples incubated with different organic residue $\mathrm{C}$ rates was approximately $8 \mathrm{~mL}$. The tubes containing soil combined with organic residue $\mathrm{C}$ rates were weighed every 5 days, and deionized water was added when necessary to maintain the weight established at the onset of the experiment.

After the incubation period, SOC was extracted according to the method proposed by Scaglia \& Adani (2009), with the following modifications: approximately $7.5 \mathrm{~mL}$ of deionized water was added to each tube containing soil combined with organic residue $\mathrm{C}$ rates, which were homogenized by hand and then mechanical agitation (125 rpm for $40 \mathrm{~min}$ ); subsequently, the samples were centrifuged at 9,000 rpm for $15 \mathrm{~min}$, after which the $\mathrm{pH}$ and $\mathrm{EC}$ readings were taken. After these steps, the samples were centrifuged again at 9,000 rpm for $15 \mathrm{~min}$ and filtered through a $0.45-\mu \mathrm{m}$ pore membrane. The WETC, WEOC, and WEIC levels were determined using an Elementar Vario Cube TOC automatic analyzer in the liquid module.

Organic C was extracted from soil samples treated with increasing rates of quail and chicken manure using $\mathrm{KH}_{2} \mathrm{PO}_{4}$. Thus, after the extraction with water, a further extraction with $0.1 \mathrm{~mol} \mathrm{~L}^{-1} \mathrm{KH}_{2} \mathrm{PO}_{4}$ was performed by adding approximately $5 \mathrm{~mL}$ of extraction solution to the tubes containing soil combined with organic residue $\mathrm{C}$ rates. After this step, the samples were agitated ( $125 \mathrm{rpm}$ for $40 \mathrm{~min}$ ), centrifuged (9,000 rpm for $15 \mathrm{~min}$ ), and filtered through a membrane with a $0.45-\mu \mathrm{m}$ pore diameter. The TC- $\mathrm{KH}_{2} \mathrm{PO}_{4}$, OC$\mathrm{KH}_{2} \mathrm{PO}_{4}$, and IC- $\mathrm{KH}_{2} \mathrm{PO}_{4}$ contents were quantified using the aforementioned TOC automatic analyzer. The study was conducted at the Laboratory of Soil Organic Matter Study (LEMOS) - DCS/UFLA.

The data obtained were subjected to analysis of variance (ANOVA) and regression analysis using the SISVAR statistical program (Ferreira, 2003), with significance set at 5 . Linear correlation analyses were also performed for the soil WETC levels, C/N ratio, and $\mathrm{N}$ content of the residues, as well as with the soil $\mathrm{pH}$ levels, where the degree of association between the variables was evaluated based on the correlation coefficients and their degrees of significance.

\section{RESULTS AND DISCUSSION}

\section{The pH and electrolytic conductivity}

Increasing the residue $\mathrm{C}$ rates increased the $\mathrm{pH}$ of the soil samples treated with organic residues, with the exception of sewage sludge, which acidified the soil with increasing residue $\mathrm{C}$ rates (Figure 1a). Adding $20,000 \mathrm{mg} \mathrm{kg}^{-1}$ of sewage sludge-C decreased the soil $\mathrm{pH}$ by one unit compared to the treatment without applying the sludge $\left(0 \mathrm{mg} \mathrm{kg}{ }^{-1}\right.$ residue $\left.\mathrm{C}\right)$. Soil acidification occurs due to the low $\mathrm{pH}$ (3.4) of the nonlimed sludge. Similar effects were observed by other researchers (Epstein et al., 1976; Nascimento et al., 2004; Singh \& Agrawal, 2010), although Oliveira et al. (2002) found that applying sewage sludge at rates of 33,66 , and 99 t ha $^{-1}$ (dry basis) caused immediate increases in the soil $\mathrm{pH}$, due to the alkalinity of the material used.

Among the residues used, the chicken and quail manure provided the highest increases in soil $\mathrm{pH}$ (Figure 1a). At the highest rates of chicken and quail manure, the soil samples exhibited $\mathrm{pH}$ values of 7.3 and 7.4 in water, respectively, which lie above the optimal $\mathrm{pH}$ range (5.5 to 6.5) recommended for most crops (Duarte, 2010). However, according to Ernani \& Gianello (1983), the increase in pH occurs immediately after adding the residues and tends to return to its initial value over time.

The quantity of chicken manure added to obtain residue $\mathrm{C}$ rates equivalent to the rates of quail manure was higher because chicken manure has a lower $\mathrm{C}$ content (Table 1). Thus, adding $11,350 \mathrm{mg} \mathrm{kg}^{-1}$ of residue $\mathrm{C}$ is equivalent to $100 \mathrm{t} \mathrm{ha}^{-1}$ of chicken manure and to $89 \mathrm{t} \mathrm{ha}^{-1}$ of quail manure in the $0-20 \mathrm{~cm}$ soil layer. Adding these quantities of chicken and quail manure to the soil increases the $\mathrm{pH}$ from 6.0 to 6.6 and 7.0, respectively. This result shows that the liming potential of quail manure is higher than that of chicken manure, given that adding lower quantities 


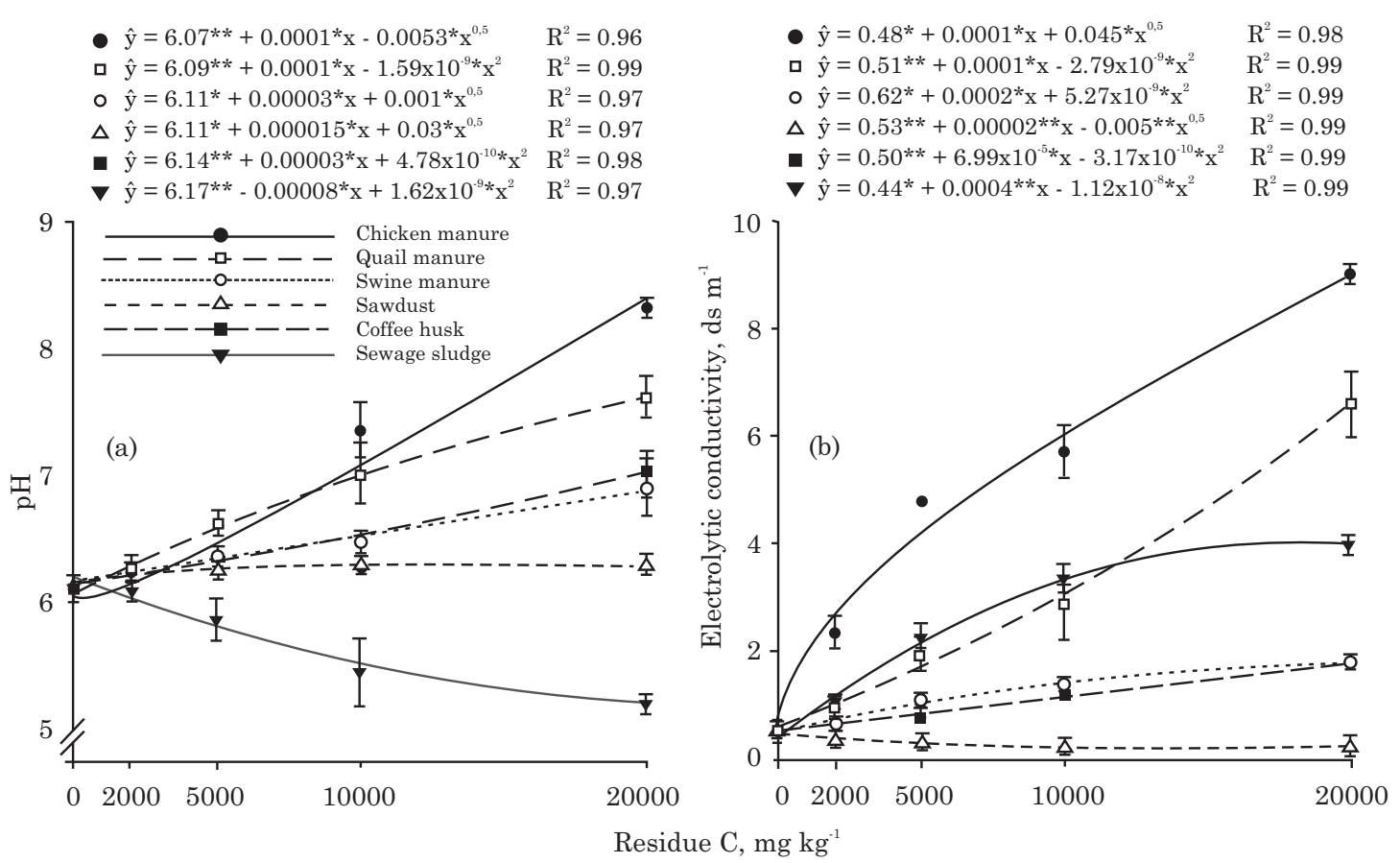

Figure 1. Soil pH (a) and EC (b) in response to increasing $\mathrm{C}$ levels in organic residues.

of quail manure results in higher soil $\mathrm{pH}$. Both chicken and quail manure have similar $\mathrm{pH}$ values (Table 1), which means that, in addition to the rate applied, constituents of these manure types other than hydrogen concentration regulate the increases in soil $\mathrm{pH}$ reported in this study.

In fact, the changes in soil $\mathrm{pH}$ that result from adding organic residues may be related to, among other factors, the cations levels present in the materials and consequently to soluble organic anions (Marschner $\&$ Noble, 2000; Miyazawa et al., 2000).

Applying increasing residue $\mathrm{C}$ levels increased the $\mathrm{EC}$ of the soil samples treated with chicken and quail manure (Figure 1b). In contrast to the other residues, $\mathrm{EC}$ was not increased by sawdust. Based on the squareroot regression model $\left(\hat{\mathrm{y}}=0.53^{* *}+0.00002^{* *} \mathrm{x}\right.$ $0.005^{* *} \mathrm{x}^{0.5} \mathrm{R}^{2}=0.99$ ), an EC of $0.2 \mathrm{dS} \mathrm{cm}^{-1}$ was obtained by applying $16,997 \mathrm{mg} \mathrm{kg}^{-1}$ residue $\mathrm{C}$ from sawdust. In the treatment without application of this material $\left(0 \mathrm{mg} \mathrm{kg}^{-1}\right)$, the $\mathrm{EC}$ was $0.5 \mathrm{dS} \mathrm{cm}^{-1}$. Applying sewage sludge at a $9,000 \mathrm{mg} \mathrm{kg}^{-1} \mathrm{C}$ dose increased the EC of the soil samples. From this concentration further, however, the increases in conductivity were not proportional to the quantity of residue added. The agricultural use of sewage sludge can increase soil EC (Logan et al., 1997) and cause seasonal salinization effects, thereby compromising plant growth and development depending on climate, soil type, and the application rate and frequency (Bevacqua \& Mellano, 1994).

A quadratic increase in EC was obtained when applying rates of coffee husk and swine manure. The maximum EC obtained when applying swine manure was $1.4 \mathrm{dS} \mathrm{m}^{-1}$ at a concentration of $17,921 \mathrm{mg} \mathrm{kg}^{-1}$ residue $\mathrm{C}$. A similar EC value was only obtained by adding $400 \mathrm{mg} \mathrm{kg}^{-1} \mathrm{C}$-chicken manure. This result reflects the effect of adding higher quantities of chicken manure, due to its lower $\mathrm{C}$ content, in addition to the higher EC value of this residue compared to swine manure (Table 1).

The EC values of soil treated with swine manure, coffee husk, and sawdust remained below $2.0 \mathrm{dS} \mathrm{m}^{-1}$ (considered a good condition, though some crops are sensitive to salts at EC $<2.0 \mathrm{dS} \mathrm{m}^{-1}$ ) at all rates evaluated (Alberta Environmental Protection, 2010). It is however noteworthy, that when determining this property, the soil:water ratio was 1:0.8, i.e., more diluted than the reference value in the saturation extract reported by Jones Junior (1983). Values above $2.0 \mathrm{dS} \mathrm{m}^{-1}$ were obtained by adding chicken manure, sewage sludge and quail manure at the following rates of organic residue C: $1,143,4,500$, and $6,000 \mathrm{mg} \mathrm{kg}^{-1}$, respectively. However, under field conditions, it is believed that the EC values may be lower than the values found under the conditions evaluated in this study, because ion uptake by plants, for example, contributes to reducing soil EC (Caovilla et al., 2005). Furthermore, ion leaching minimizes the possible effects associated with salinity in open farming systems and in regions with regular rainfall during the plant growth cycle.

\section{Water extractable carbon and phosphate}

Except for sewage sludge, water-extractable C levels were observed to increase with increasing $\mathrm{C}$ levels in organic residues (Figure 2a,b,c). Since WEOC 

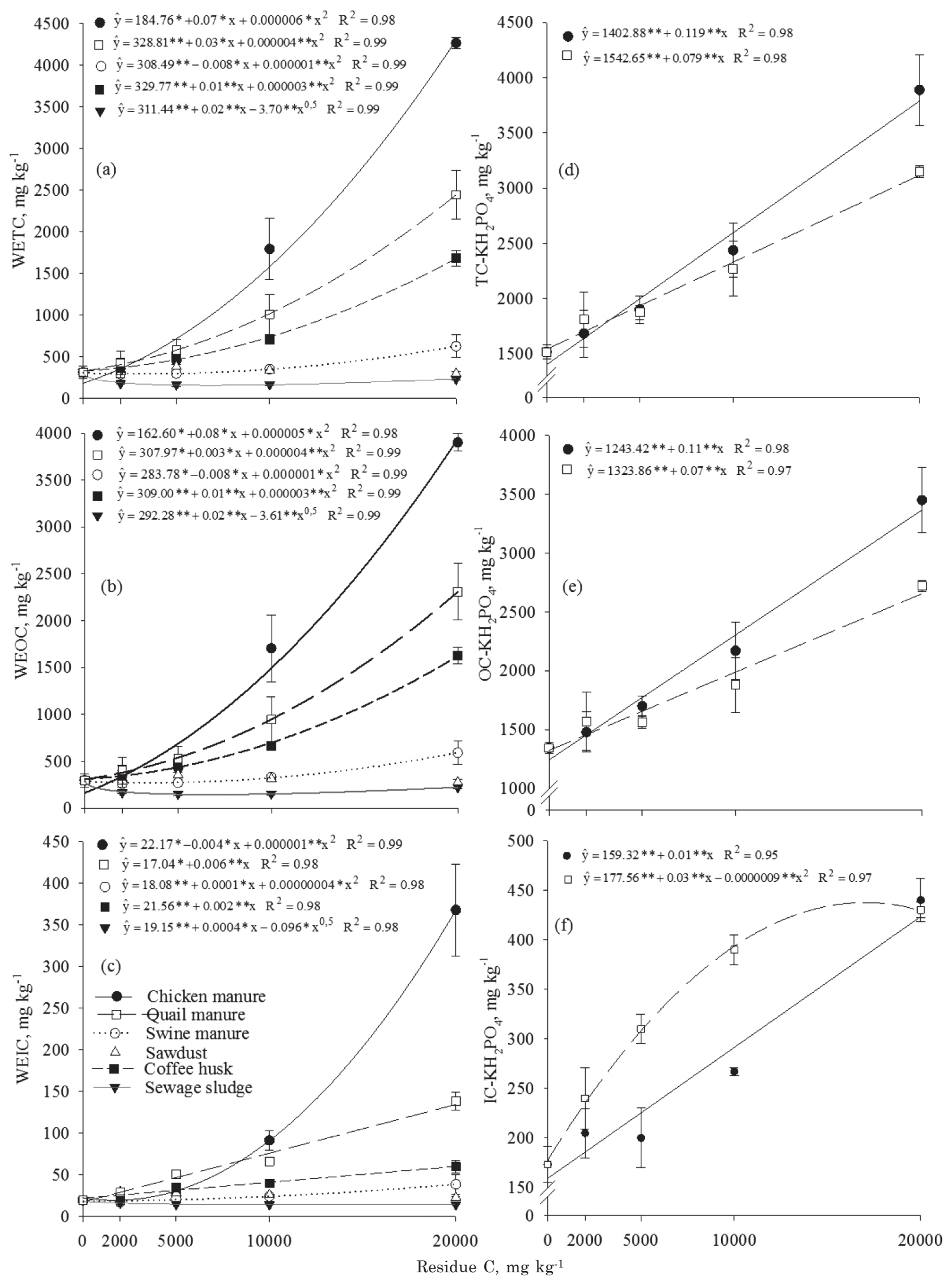

Figure 2. Levels of water-extractable total carbon (WETC), water-extractable organic carbon (WEOC), waterextractable inorganic carbon (WEIC), total carbon $\left(\mathrm{TC}-\mathrm{KH}_{2} \mathrm{PO}_{4}\right)$, organic carbon $\left(\mathrm{OC}_{-} \mathrm{KH}_{2} \mathrm{PO}_{4}\right)$, and inorganic carbon ( $\mathrm{IC}-\mathrm{KH}_{2} \mathrm{PO}_{4}$ ) extracted by $\mathrm{KH}_{2} \mathrm{PO}_{4}$ in response to increasing residue $\mathrm{C}$ levels. 
constituted the largest total C fraction (approximately $94 \%$ ), this portion will be more emphasized. However, in studies addressing soil $\mathrm{C}$ dynamics in the system in more detail, knowledge about the inorganic $\mathrm{C}$ levels is important (Wang \& Alva, 1999).

The residues that induced the highest levels of WETC, WEOC, and WEIC were chicken and quail manure and coffee husk; soil WEOC levels of 3,700, 2,468 , and $1,749 \mathrm{mg} \mathrm{kg}^{-1}$ were obtained when adding the highest dose of these residues, respectively. The higher $\mathrm{pH}$ observed mainly in the soil samples treated with chicken and quail manure (Figure 1a), among other factors, may explain the higher WEOC levels obtained. Although the $\mathrm{C} / \mathrm{N}$ ratio is an index to predict the decomposition rate of organic matter (the higher the $\mathrm{C} / \mathrm{N}$ ratio of a substrate, the lower the decomposition rate) (Melillo et al., 1982), according to Taylor et al. (1991), the lignin content, nutrient (especially N) and phenol concentrations and the SOC content of the residues are also considered main reduction factors of the decomposition speed. In this study, there was a significant positive correlation at $1 \%$ probability between the soil $\mathrm{pH}$ and WETC and between the residue $\mathrm{N}$ content and the soil WETC content, but there was no correlation between the $\mathrm{C} / \mathrm{N}$ ratio of the residues and the soil WETC content (Table 2).

Unlike in the treatments with coffee husk, the WEOC levels do not reflect the $\mathrm{C} / \mathrm{N}$ ratio of this residue. For example, sewage sludge has a lower $\mathrm{C} / \mathrm{N}$ ratio but did not increase the soil WEOC content. Coffee husk applications to the soil increased the $\mathrm{pH}$ (Figure 1a), which may have increased the mineralization rate of organic matter, thus inhibiting the effect of the chemical composition of the residue on the mineralization process (Khalil et al., 2005). In addition to the $\mathrm{C} / \mathrm{N}$ ratio, the soluble forms of $\mathrm{C}$ in the residue are also properties that can predict their decomposition rates (Trinsoutrot et al., 2000). Significant increases in SOC after adding manure and compounds to the soil were found by Chantigny et al. (2002), and these changes were attributed to soluble molecules present in the residues.

An important issue related to the agricultural use of chicken and quail manure are the relatively higher $\mathrm{N}$ levels of these manure types and, therefore, lower $\mathrm{C} / \mathrm{N}$ ratios than of other residues, indicating that these material may constitute immediate $\mathrm{C}$ sources for plants. The application of residues with high $\mathrm{N}$ levels

Table 2. Matrix of linear correlation for WETC, soil $\mathrm{pH}, \mathrm{N}$ content, and $\mathrm{C} / \mathrm{N}$ ratio of the residues

\begin{tabular}{lc}
\hline Variable & Soil WETC \\
\hline Soil pH & $0.86^{* *}$ \\
N content of the residues & $0.81^{* *}$ \\
C/N ratio of the residues & 0.38 \\
WETC of the residues & $0.92^{* *}$ \\
\hline
\end{tabular}

WETC, water-extractable total carbon. ${ }^{* *}$ Significant at $1 \%$. and low chemical stability to the soil must be performed carefully, observing the rates, soil type, and application method, to avoid nitrate leaching. The continued use of high manure rates may result in adverse effects on soil properties, with probable negative consequences for the plants, as has been shown here for $\mathrm{pH}$ and EC. Thus, it is recommended that manure applications should be based on previously established agronomic and technical aspects, in the nutritional requirement of the crop (mainly N), the moisture content and chemical composition of the residue, and in the current legislation on agricultural use and the maximum loads of pollutants to be added to the soil (Silva, 2008).

There was a positive significant correlation between the residue WETC content and the soil WETC content (Table 2). The organic $\mathrm{C}$ in the residues is composed of two fractions with different degrees of biodegradability, and their biological degradation depends on the degradation rate of a wide variety of C compounds present in the sample (e.g., carbohydrates, amino acids, fatty acids, lignin) and their nutrient content (Bernal et al., 1998). The chicken and quail manure are rapidly mineralized by microorganisms because they have higher WETC levels (Table 1) and therefore release more SOC into the soil.

Based on the regression equation $\left(\hat{\mathrm{y}}=311.44^{* *}+\right.$ $\left.0.02 * * \mathrm{x}-3.70 * * \mathrm{x}^{0.5} \mathrm{R}^{2}=0.99\right)$, decreases in the WETC levels were observed up to a concentration of $8,550 \mathrm{mg} \mathrm{kg}^{-1} \mathrm{C}$ (sewage sludge). At higher concentrations, the WETC levels increased, but not to values above the dose of $311 \mathrm{mg} \mathrm{kg}^{-1}$ (value of the treatment without addition of residue $\mathrm{C}$ ) (Figure $2 \mathrm{a}$ ). The $\mathrm{pH}$ of the soil treated with sewage sludge was lower than when treated with residue $\mathrm{C}$ rates (Figure 1a), which may explain the $C$ decreases (Figure 2a,b,c). According to Michalzik \& Matzner (1999), the release of dissolved organic $\mathrm{C}$ from organic matter increases at higher temperature and higher $\mathrm{pH}$ and decreases at higher $\mathrm{C} / \mathrm{N}$ ratio of the residue.

With regard to sawdust, no model was obtained to explain the initial behavior of the increase followed by a decrease (from $2,000 \mathrm{mg} \mathrm{kg}^{-1}$ ) in the $\mathrm{C}$ concentrations evaluated in this study. Significant increases in the WETC, WEOC, and WEIC (23.6, 21.7 , and $52.6 \%$, respectively) were obtained at the dose of $2,000 \mathrm{mg} \mathrm{kg}^{-1}$ residue $\mathrm{C}$ compared to the lowest dose ( $0 \mathrm{mg} \mathrm{kg}^{-1}$ residue $\left.\mathrm{C}\right)$. The $\mathrm{C} / \mathrm{N}$ ratio of sawdust is high (Table 1), which hinders the release of labile $\mathrm{C}$ that contributes to increase the SOC levels.

Applying increasing residue $\mathrm{C}$ rates of quail manure and coffee husk linearly increased the WEIC levels (Figure 2c). A quadratic increase was observed in the treatments with rates of swine and chicken manure, with maximum values of 38 and $367 \mathrm{mg} \mathrm{kg}^{-1}$ of WEIC, respectively. The materials with the highest increases in the WEIC values were as follows, in ascending order: chicken manure $>$ quail manure $>$ 
coffee husk $>$ swine manure $>$ sawdust. The properties of the residues are related to factors including their production process, animal age, feed type, and degree of composting (Abad et al., 2002; Abreu Junior et al., 2005; Silva, 2008). The feed type animals are fed with influences the manure quality; many poultry farmers use lime in feeds, which explains the higher WEIC values found in the soil treated with rates of quail and chicken manure.

With $\mathrm{KH}_{2} \mathrm{PO}_{4}$, high $\mathrm{C}$ quantities could be extracted from the soil treated with chicken and quail manure. Linear increases (in the studied range) in the levels of TC- $\mathrm{KH}_{2} \mathrm{PO}_{4}, \mathrm{OC}-\mathrm{KH}_{2} \mathrm{PO}_{4}$, and IC- $\mathrm{KH}_{2} \mathrm{PO}_{4}$ with increasing residue $\mathrm{C}$ levels were observed (Figure $2 \mathrm{~d}$, e, f), except for IC- $\mathrm{KH}_{2} \mathrm{PO}_{4}$, where there was a quadratic increase in relation to increasing residue $\mathrm{C}$ levels in quail manure (Figure $2 \mathrm{f}$ ). The $\mathrm{C}$ quantities extracted by $\mathrm{KH}_{2} \mathrm{PO}_{4}$ were higher than the quantities extracted by water for all concentrations of residue $\mathrm{C}$ applied in chicken and quail manure; the mean levels of TC- $\mathrm{KH}_{2} \mathrm{PO}_{4}$ were 1.6 and 2.2 times as high, respectively, than WETC in the treatments with chicken and quail manure. According to Zsolnay (1996), highly water-soluble molecules, such as glucose and amino acids, may be distributed between desorbed and sorbed forms. Considering the equilibrium of adsorption and desorption of soil SOC, it is possible to find a portion of $\mathrm{C}$ stored in the soil, even after extraction with water (Tao \& Lin, 2000), as observed in the present study. The remaining quantity of SOC in the solid phase of the soil depends on the soil properties and SOC itself (Tao \& Lin, 2000). Soil can adsorb organic acids with high energy (Haynes, 1984), and Oxisols, especially the dystrophic Red Latosol used in this study, which is an oxidic soil, have a greater ability to adsorb anions than less weathered soil (Novais \& Smyth, 1999).

In a study that aimed to evaluate the effect of the extractor on the quantities of SOC extracted from samples of mineral soils under forests, Rennert et al. (2007) found that the mean quantities of SOC extracted were higher using $0.5 \mathrm{~mol} \mathrm{~L}^{-1} \mathrm{~K}_{2} \mathrm{SO}_{4}$, followed by water and then by $0.01 \mathrm{~mol} \mathrm{~L}^{-1} \mathrm{CaCl}_{2}$. The quantities of SOC extracted by water and by $0.5 \mathrm{~mol} \mathrm{~L}^{-1} \mathrm{~K}_{2} \mathrm{SO}_{4}$ reached maximum values of 164 and $126 \mathrm{mg} \mathrm{kg}^{-1}$, respectively. For the treatment without chicken manure application $\left(0 \mathrm{mg} \mathrm{kg}^{-1} \mathrm{C}\right)$, the quantities of SOC extracted by water and by $0.1 \mathrm{~mol} \mathrm{~L}^{-1} \mathrm{KH}_{2} \mathrm{PO}_{4}$ were 295 and $1,345 \mathrm{mg} \mathrm{kg}^{-1}$, respectively, i.e., higher than the values reported by Rennert et al. (2007), who considered mainly the fraction extracted with $\mathrm{KH}_{2} \mathrm{PO}_{4}$.

Standardizing a method for extracting SOC is important for comparing the results from different studies. In addition to the concentration and type of extractor, it is believed that the following other factors influence the results obtained, even for the same soil sample:extraction time, sample moisture, soil:extraction solution ratio, sample storage type, and the method used to quantify the $\mathrm{C}$ levels in the extracts
(Zsolnay \& Gorlitz, 1994). Although there is no universal procedure for SOC extraction from soils (Chantigny, 2003), water, $\mathrm{CaCl}_{2}$, and $\mathrm{K}_{2} \mathrm{SO}_{4}$ are the most commonly used extractors (Rennert et al., 2007); therefore, the results presented here indicate the need to test $\mathrm{KH}_{2} \mathrm{PO}_{4}$ under varied conditions.

\section{CONCLUSIONS}

1. Adding organic residue $\mathrm{C}$ rates increases the soil $\mathrm{pH}$, except in the case of sewage sludge, which acidifies the soil. Chicken and quail manure increase the soil $\mathrm{pH}$ to values above the recommended for cultivation of most crops.

2 . The soil electrolytic conductivity increases with increasing rates of manure (chicken, quail, and swine), coffee husk and sludge. Values above the critical level of EC are obtained by adding chicken manure, sewage sludge and quail manure at rates of $1,143,4,500$, and $6,000 \mathrm{mg} \mathrm{kg}^{-1}$ of organic residue $\mathrm{C}$, respectively.

3. Except for sewage sludge, adding organic residues to the soil increases the water-extractable carbon levels, especially at the highest application rates of less decomposed nutrient-rich manure, such as chicken and quail manure.

4. The SOC quantities extracted by potassium phosphate are 1.6 to 2.2 times higher, respectively, in treatments with chicken and quail manure, than those extracted by water, showing that a portion of the SOC is adsorbed by the colloids of the Oxisol studied.

\section{ACKNOWLEDGEMENTS}

The authors gratefully acknowledge the funding of this research by the Research Foundation of the State of Minas Gerais - Fapemig (Process CAG APQ5362-3. 08/07); and are indebted to the Brazilian Federal Agency for Support and Evaluation of Graduate Education - CAPES, for granting the doctoral/postdoctoral scholarship to the first author of this study; and to Brazilian Council for Scientific and Technological Development - CNPq (Process 308592011-5), for granting research scholarships.

\section{LITERATURE CITED}

ABAD, M.; NOGUERA, P.; PUCHADES, R.; MAQUIEIRA, A. \& NOGUERA, V. Physico-chemical and chemical properties of some coconut coir dusts for use as a peat substitute for containerized ornamental plants. Bioresour. Technol., 82:241-245, 2002. 
ABREU JUNIOR, C.H.; BOARETTO, A.E.; MURAOKA, T. \& KIEHL, J.C. Uso agrícola de resíduos orgânicos potencialmente poluentes: Propriedades químicas do solo e produção vegetal. In: TORRADO, P.V.; ALLEONI, L.R.F.; COOPER, M.; SILVA, A.P. \& CARDOSO, E.J., eds. Tópicos em ciência do solo. Viçosa, MG, Sociedade Brasileira de Ciência do Solo, 2005. v.4, p.391-470.

ABREU JUNIOR, C.H.; MURAOKA, T.; LAVORANTE, A.F. \& ALVAREZ V., F.C. Condutividade elétrica, reação do solo e acidez potencial em solos adubados com composto lixo. R. Bras. Ci. Solo, 24:645-657, 2000.

ALBERTA ENVIRONMENTAL PROTECTION. Alberta Tier 1 soil and groundwater remediation guidelines. Edmonton, Alberta Environmental Protection, 2010.

ASMAR, F.; EILAND, F. \& NIELSEN, N.E. Effect of extracellular- enzyme activities on solubilization rate of soil organic nitrogen. Biol. Fertil. Soils,17:32-38, 1994.

AQUinO NETO, V. \& CAMARGO, O.A. Crescimento e acúmulo de crômio em alface cultivada em dois Latossolos tratados com $\mathrm{CrCl}_{3}$ e resíduos de curtume. R. Bras. Ci. Solo, 24:225-235, 2000.

BAZIRAMAKENGA, R.; SIMARD, R.R. \& LEROUX, G.D. Determination of organic acids in soil extracts by ion chromatography. Soil Biol. Biochem., 27:349 -356, 1995.

BERNAL, M.P.; SÁNCHEZ-MONEDERO, M.A.; PAREDES, C. \& ROIG, A. Carbon mineralization from organic wastes at different composting stages during their incubation with soil. Agric. Ecosyst. Environ., 69:175-189, 1998.

BEVACQUA, R.F. \& MELLANO, V.J. Cumulative effects of sludge compost on crop yields and soil properties. Commun. Soil Sci. Plant Anal., 25:395-406, 1994.

BOLAN, N.S.; NAIDU, R.; MAHIMAIRAJA, S. \& BASKARAN, S. Influence of low-molecular-weight organic acids on the solubilization of phosphates. Biol. Fertil. Soils,18:311319, 1994.

CAOVILLA, F.A.; SAMPAIO, S.C.; PEREIRA, J.A.; VILAS BOAS, M.A.; GOMES, B.M. \& FIGUEIRÊDO, A.D. Lixiviação de nutrientes provenientes de águas residuárias em colunas de solo cultivado com soja. R. Bras. Eng. Agríc. Amb., 9:283-287, 2005.

CERNÝ, J.; BALÍK, J.; PAVLÍKOVÁ, D.; ZÍTKOVÁ, M. \& SÝKORA, K. The influence of organic and mineral nitrogen fertilizers on microbial biomass nitrogen and extractable organic nitrogen in long-term experiments with maize. Plant Soil Environ., 49:560-564, 2003.

CHANTIGNY, M.H. Dissolved and water-extractable organic matter in soils: A review on the influence of land use and management practices. Geoderma, 113:357-380, 2003.

CHANTIGNY, M.H.; ANGERS, D.A. \& ROCHETTE, P. Fate of carbon and nitrogen from animal manure and crop residues in wet and cold soils. Soil Biol. Biochem., 34:509$517,2002$.

CIOTTA, M.N.; BAYER, C.; ERNANI, P.R.; FONTOURA, S.M.V.; WOBETO, C. \& ALBUQUERQUE, J.A. Manejo da calagem e os componentes da acidez de Latossolo Bruno em plantio direto. R. Bras. Ci. Solo, 28:317- 326, 2004.
DUARTE, F.V. Influência da aplicação de gás carbônico na redução de precipitação de carbonatos em sistema de irrigação localizada. Belo Horizonte, Universidade Federal de Minas Gerais, 2010. 108p. (Tese de Doutorado)

ERNANI, P.R. \& GIANELLO, C. Diminuição do alumínio trocável do solo pela incorporação de esterco de bovinos e camas de aviário. R. Bras. Ci. Solo, 7:161-165, 1983.

EPSTEIN, E.; TAYLOR, J.M. \& CHANEY, R.L. Effects of sewage sludge and sludge compost applied to soil on some soil physical and chemical properties. J. Environ. Qual., 5:422-426, 1976 .

FERREIRA, D.F. SISVAR software: Versão 4.6. Lavras, DEX/ UFLA, 2003.

FIA, R.; MATOS, A.T. \& AGUIRRE, C.I. Características químicas de solo adubado com doses crescentes de lodo de esgoto caleado. Eng. Agric., 13:287-299, 2005.

FRANCHINI, J.C.; MALAVOLTA, E.; MIYAZAWA, M. \& PAVAN, M.A. Alterações químicas em solos ácidos após a aplicação de resíduos vegetais. R. Bras. Ci. Solo, 23:533$542,1999$.

Gigliotti, G.; GIUSQUiAnI, P.L.; BUSINELLI, D. \& MACCHIONI, A. Composition changes of dissolved organic matter in a soil amended with municipal waste compost. Soil Sci., 162:919-926, 1997.

GONET, S.S. \& DEBSKA, B. Dissolved organic carbon and dissolved nitrogen in soil under different fertilization treatments. Plant Soil Environ., 52:55-63, 2006.

HAYNES, R.J. Lime and phosphate in the soil-plant system. Adv. Agron., 37:249-315, 1984.

HIGASHIKAWA, F.S.; SILVA, C.A. \& BETTIOL, W. Chemical and physical properties of organic residues. R. Bras. Ci. Solo, 34:1743-1752, 2010.

INÁCIO, E.S.B. Distribuição vertical de carbono orgânico em Latossolo sob diferentes usos. Lavras, Universidade Federal de Lavras, 2009. 86p. (Tese de Doutorado)

JONES JUNIOR, J.B. A guide for the hydroponic and soilless culture grower. Portland, Timber Press, 1983. 124p.

KHALIL, M.I.; HOSSAIN, M.B. \& SCHMIDHALTER, U. Carbon and nitrogen mineralization in different upland soils of subtropic treated with organic materials. Soil Biol. Biochem., 37:1507-1518, 2005.

KENNEDY, J.; BILLETT, M.F.; DUTHIE, D.; FRASER, A.R. \& HARRISON, A.F. Organic matter retention in an upland humic Podzol; the effects of $\mathrm{pH}$ and solute type. Eur. J. Soil Sci,. 47:615-625, 1996.

LOGAN, T.J.; LINDSAY, B.J.; GOINS, L.E. \& RYAN, J.A. Field assessment of sludge metal bioavailability to crops: Sludge rate response. J. Environ. Qual., 26:534-550, 1997.

MADHUN, Y.A.; YOUNG, J.L. \& FREED, V.H. Binding of herbicides by water-soluble organic materials from soil. J. Environ. Qual., 15:64-68, 1986.

MARSCHNER, B. \& KALBITZ, K. Controls of bioavailability and biodegradability of dissolved organic matters in soils. Geoderma, 13:211-235, 2003. 
MARSCHNER, B. \& NOBLE, A.D. Chemical and biological processes leading to the neutralization of acidity in soil incubated with litter materials. Soil Biol. Biochem., 32:805$813,2000$.

MELILLO, J.M.; ABER, J.D. \& MURATORE, F.J. Nitrogen and lignin control of hardwood leaf litter decomposition dynamics. Ecology, 63:621-626, 1982.

MELO, L.C.A.; SILVA, C.A. \& DIAS, B.O. Caracterização da matriz orgânica de resíduos de origens diversificadas. R. Bras. Ci. Solo, 32:101-110, 2008.

METTING, F.B. Structure and physiological ecology of soil microbial communities. In: METTING, F.B., ed. Soil microbial ecology-application in agricultural and environmental management. New York, Marcel Dekker, 1993. p.3-24.

MICHALZIK, B. \& MATZNER, E. Dynamics of dissolved organic nitrogen and carbon in a Central European Norway spruce ecosystem. Eur. J. Soil Sci., 50:579-590, 1999.

MKHABELA, M.S. \& WARMAN, P.R. The influence of municipal solid waste compost on yield, soil phosphorus availability and uptake by two vegetable crops grown in a Pugwash sandy loam soil in Nova Scotia. Agric. Ecosyst. Environ., 106:57-67, 2005.

MIYAZAWA, M.; PAVAN, M.A. \& FRANCHINI, J.C. Neutralização da acidez do perfil do solo por resíduos vegetais. Inf. Agron., 92:1-8, 2000. (Encarte técnico)

MONTEMURRO, F. \& MAIORANA, M. Organic fertilization as resource for a sustainable agriculture. In: ELSWORTH, L.R. \& PALEY, W.O., eds. Fertilizers: Properties, applications and effects. New York, Nova Science Publishers, 2008. p.123-146.

MONTEMURRO, F.; CONVERTINI, G. \& FERRI, D. Mill wastewater and olive pomace compost as amendments for rye-grass. Agronomie, 24:481- 486, 2004.

NASCIMENTO, C.W.A.; BARROS, D.A.S.; MELO, E.E.C. \& OLIVEIRA, A.B. Alterações químicas em solos e crescimento de milho e feijoeiro após aplicação de lodo de esgoto. R. Bras. Ci. Solo, 28:385-392, 2004.

NEGRIN, M.A.; ESPINO-MESA, M. \& HERNANDEZMORENO, J.M. Effect of water:soil ratio on phosphate release: $\mathrm{P}$, aluminium and fulvic acid associations in water extracts from Andisols and Andic soils. Eur. J. Soil Sci., 47:385-393, 1996.

NOVAIS, R.F. \& SMYTH, T.J. Fósforo em solo e planta em condições tropicais. Viçosa, MG, Universidade Federal de Viçosa, 1999. 399p.

OLIVEIRA, F.C.; MATTIAZZO, M.E.; MARCIANO, C.R. \& ROSSETTO, R. Efeitos de aplicações sucessivas de lodo de esgoto em um Latossolo Amarelo distrófico cultivado com cana-de-açúcar: Carbono orgânico, condutividade elétrica, pH e CTC. R. Bras. Ci. Solo, 26:505-519, 2002.

OLIVEIRA, F.C. Disposição de lodo de esgoto e composto de lixo urbano num Latossolo Vermelho-Amarelo cultivado com cana-de-açúcar. Piracicaba, Escola Superior de Agricultura Luiz de Queiroz, 2000. 247p. (Tese de Doutorado)
PINHEIRO, G.L.; SILVA, C.A.; LIMA, J.M.; SACZK, A.A. \& COSTA, A.L. Ácidos orgânicos de baixa massa molar em solos e materiais orgânicos. Quím. Nova, 36:413418, 2013.

RAIJ, B.van. Fertilidade do solo e adubação. Piracicaba, Ceres/ Potafos, 1991. 343p.

RENNERT, T.; GOCKEL, K.F. \& MANSFELDT, T. Extraction of water-soluble organic matter from mineral horizons of forest Soils. Plant Nutr. Soil Sci., 170:514-521, 2007.

SCAGLIA, B. \& ADANI, F. Biodegradability of soil water soluble organic carbon extracted from seven different soils. J. Environ. Sci., 21: 641-646, 2009.

SHEN, Y.; STROM, L.; JONSSON, J.A. \& TYLER, G. Lowmolecular organic acids in the rhizosphere soil solution of beech forest (Fagus sylvatica L.) Cambisols determined by ion chromatography using supported liquid membrane enrichment technique. Soil Biol. Biochem., 28:1163-1169, 1996.

SILVA, C.A. Uso de resíduos orgânicos na agricultura. In: SANTOS, G.A.; SILVA, L.S.; CANELLAS, L.P. \& CAMARGO, R.A.O., eds. Fundamentos da matéria orgânica do solo: Ecossistemas tropicais e subtropicais. 2.ed. Porto Alegre, Metrópole, 2008. p.113-136.

SINGH, R.P. \& AGRAWAL, M. Variations in heavy metal accumulation, growth and yield of rice plants grown at different sewage sludge amendment rates. Ecotoxicol. Environ. Saf., 73: 632-641, 2010.

SOLINGER, S.; KALBITZ, K. \& MATZNER, E. Controls on the dynamics of dissolved organic carbon and nitrogen in a Central European deciduous forest. Biogeochemistry, 55:327-349, 2001.

TAO, S. \& LIN, B. Water soluble organic carbon and its measurement in soil and sediment. Water Res., 34:1751$1755,2000$.

TAYLOR, B.R.; PRESCOTT, C.E.; PARSONS, W.J.F. \& PARKINSON, D. Substrate control of litter decomposition in four Rock Mountain coniferous forests. Can. J. Bot., 69:2242-2250, 1991

TEIXEIRA, S.T.; MELO, W.J. \& SILVA, E.T. Aplicação de lodo da estação de tratamento de água em solo degradado. Pesq. Agropec. Bras., 40:91-94, 2005.

TRINSOUTROT, I.; RECOUS, S.; BENTZ, B.; LINÈRES, M.; CHÈNEBY, D. \& NICOLARDOT, B. Biochemical quality of crop residues and carbon and nitrogen mineralization kinetics under non-limiting nitrogen conditions. Soil Sci. Soc. Am. J., 64:918-926, 2000.

XU, J.M.; TANG, C. \& CHEN, Z.L. Chemical composition controls residue decomposition in soils differing in initial pH. Soil Biol. Biochem., 38:544-552, 2006.

ZHANG, M.; HEANEY, D.; HENRIQUEZ, B.; SOLBERG, E. \& BITTNER, E. A four-year study on influence of biosolids/ MSW compost application in less productive soils in Alberta: nutrient dynamics. Comp. Sci. Util., 14:68-80, 2006. 
ZHELJAZKOV, V.D. \& WARMAN, P.R. Source-separated municipal solid waste compost application to Swiss chard and basil. J. Environ. Qual., 33:542-552, 2004.

ZSOLNAY, A. Dissolved humus in soil waters. In: PICCOLO, A., ed. Humic substances in terrestrial ecosystems. Amsterdam, Elsevier, 1996. p.171-223.

ZSOLNAY, A. \& GORLITZ, H. Water-extractable organicmatter in arable soils: Effects of drought and long-term fertilization. Soil Biol. Biochem., 26:1257-1261, 1994.
ZSOLNAY, A. \& STEINDL, H. Geovariability and biodegradability of water-extractable organic material in an agricultural soil. Soil Biol. Biochem., 23:1077-1082, 1991.

WANG, F.L. \& ALVA, A.K. Transport of soluble organic and inorganic carbon in sandy soils under nitrogen fertilization. Can. J. Bot., 79:303 -310, 1999.

WRIGHT, A.L.; PROVIN, T.L.; HONS, F.M.; ZUBERER, D.A. \& WHITE, R.H. Dissolved organic carbon in soil from compost-amended bermudagrass turf. Hortscience, 40:830-835, 2005. 